\title{
The Effects of COVID-19 Measures on Air Pollutant Concentrations at Urban and Traffic Sites in Istanbul
}

\author{
Ülkü Alver Şahin* \\ Environmental Engineering Department, Engineering Faculty, Istanbul University-Cerrahpaşa, Avcllar, 34320, Istanbul, \\ Turkey
}

\begin{abstract}
Since December 2019, most countries have been working to stop the spread of SARS-CoV-2, the virus responsible for COVID-19. These measures, which include restricting movement, have environmental consequences. This study assessed the impact of COVID-19 measures on air pollutant concentrations measured in urban areas and traffic stations on both the European and Asian sides of Istanbul during March 2020. Significant reductions in pollutants: $32-43 \%\left(\mathrm{PM}_{10}\right)$, 19-47\% $\left(\mathrm{PM}_{2.5}\right), 29-44 \%\left(\mathrm{NO}_{2}\right), 40-58 \%(\mathrm{CO})$ and 34-69\% $\left(\mathrm{SO}_{2}\right)$ were calculated. The clearest reductions at the traffic stations were in $\mathrm{NO}_{2}$ which originates primarily from vehicle exhaust. The reduction of $\mathrm{NO}_{2}$ at the traffic station on the European side was found higher comparing the Asian side. The average concentrations of $\mathrm{NO}_{2}, \mathrm{PM}_{2.5}, \mathrm{PM}_{10}$ and $\mathrm{CO}$ during peak traffic hours were significantly ( $\mathrm{p}<0.01)$ decreased under COVID-19 measures. The results indicate that due to the measures taken in Istanbul and across Turkey and to control the spread of the virus, anthropogenic activities such as industry, vehicle traffic and sea transport have decreased, and consequently, air pollution has been significantly reduced. These pollutant levels demonstrate the anthropogenic contribution to air pollution and can inform clean air actions in Istanbul and in others cities throughout the world.
\end{abstract}

Keywords: COVID-19; Air pollution; Istanbul; $\mathrm{NO}_{2}$; Traffic.

\section{INTRODUCTION}

The coronavirus disease (COVID-19) first broke out in Hubei Province in China in December 2019. Since that date, the Chinese government has taken measures to stop the spread of the virus. However, since February 2020. SARS-CoV-2, the virus responsible for COVID-19 has spread across almost the entire world, and each country has taken measures to attempt to stop the virus from spreading. Initially, most governments managed the crisis by giving advice such as "stay home", "maintain social distancing" and "engage only in essential activities". As a result, some countries shut down all daily activities outside the home for a period of time, and others significantly restricted activities.

COVID-19 is the most urgent threat facing humanity today, and there were more than 650000 deaths confirmed globally as of 28 July 2020 (WHO, 2020). However, air pollution is another major challenge to human health and according to the World Health Organization (WHO), every year at least 4 million deaths are related to urban air pollution. A recently published study shows that air pollution shortens

\footnotetext{
* Corresponding author.

E-mail address: ulkualver@ istanbul.edu.tr
}

lives worldwide by nearly three years on average; and leads to 8 million premature deaths annually (Lelieveld et al., 2020).

Particulate matter and gaseous air pollutants are the major components of air pollution in urban areas that impact human health and the environment. Gaseous air pollutants measured in cities include nitrogen dioxides $\left(\mathrm{NO}_{2}\right)$, sulfur dioxide $\left(\mathrm{SO}_{2}\right)$, carbon monoxide $(\mathrm{CO})$ and ozone $\left(\mathrm{O}_{3}\right)$. Human exposure to particles below $10 \mu \mathrm{m}\left(\mathrm{PM}_{10}\right)$ and below $2.5 \mu \mathrm{m}\left(\mathrm{PM}_{2.5}\right)$ can penetrate into the deepest parts of the respiratory system. Lin et al. (2017) found significant correlations between hourly peak $\mathrm{PM}_{2.5}$ and mortality. They reported that for each $10 \mu \mathrm{g} \mathrm{m}^{-3}$ increase in the hourly peaks of $\mathrm{PM}_{2.5}$, there were associated increases of $0.9 \%$ in total mortality, $1.2 \%$ in cardiovascular mortality, $0.7 \%$ in respiratory mortality. Furthermore, Mills et al. (2015) found that a $10 \mu \mathrm{g} \mathrm{m}^{-3}$ increase in $24 \mathrm{~h} \mathrm{NO}_{2}$ was associated with increases in total mortality $(0.7 \%)$, cardiovascular $(0.9 \%)$ and respiratory mortality $(1.1 \%)$.

Although there has been research on the relationship between bacteria and particulate matter (Onat et al., 2017), there are limited studies on the relationship between viruses and air pollution. One such study found a significant positive correlation between the infection rate of respiratory syncytial virus and $\mathrm{PM}_{2.5}(\mathrm{r}=0.45)$ and; $\mathrm{PM}_{10}(\mathrm{r}=0.40)$ (Croft et al., 2019). They also investigated the rate of respiratory infections, 
as measured by healthcare encounters, associated with increases in $\mathrm{PM}_{2.5}$ concentrations. The finding showed that increases in $\mathrm{PM}_{2.5}$ were associated with increased rates of emergency department visits for influenza (average, 3.9\%, range, 2.1-5.6\%). Another study has also shown that $\mathrm{PM}_{2.5}$, $\mathrm{PM}_{10}, \mathrm{NO}_{2}, \mathrm{SO}_{2}$ and $\mathrm{CO}$ were significantly correlated with respiratory tract infections in children under 3 years, and $\mathrm{PM}_{2.5}$ was significantly correlated with viral respiratory diseases in children under 7 months (Zhang et al., 2019).

$\mathrm{PM}_{2.5}$ is one of the most significant air pollutants in regards to health impacts on chronic diseases, lung diseases and respiratory problems. It has been acknowledged that these underlying health problems are strongly associated with COVID-19 mortality. This issue is currently being researched and will continue to garner attention in the future. The first study describing the link between air pollutants and COVID-19 was published by Setti et al. (2020) in Italy. They found a correlation between the number of days exceeding the limits for $\mathrm{PM}_{10}$ and the number of hospital admissions related to COVID-19.

There are major scientific and public interest questions being discussed on social media and studied intensively by academics regarding the relationship between air pollution and COVID-19, including:

1) Does air pollution increase mortality from COVID-19?

2) Does air pollution decrease during measures limiting movement to stop the spread of the virus in cities?

3) Does the COVID-19 virus remain in the air for an extended period of time (hours, days or weeks)?

4) Does the COVID-19 virus adhere to airborne particles? If so, which particle size will keep it airborne?

5) Is it possible for the COVID-19 virus to be transported over long distances on particles?

In this study, we have focused on the second question. Papers have been published from China, Barcelona and Delhi. Of particular note, Wang et al. (2020), Xu et al. (2020) and Zhao et al. (2020) investigated the effect of reduced anthropogenic activities on air pollution during the COVID-19 outbreak in China. It was reported that the decrease in $\mathrm{PM}_{2.5}$ (from 30 to $9 \mu \mathrm{g} \mathrm{m}^{-3}$ ) was smaller than expected due to unfavourable meteorological conditions. Isaifan (2020) examined air quality data during quarantine in China due to COVID-19 using satellite images from NASA. This short communication paper showed a $30 \%$ reduction in $\mathrm{NO}_{2}$ and a $25 \%$ reduction in carbon emissions compared with one year earlier. Tobías et al. (2020) examined the changes in air quality during lockdown in Barcelona during 15 days in March 2020. The study shows that the most significant reductions were seen in black carbon (BC) and $\mathrm{NO}_{2}$, primarily related to traffic emissions. In San Francisco, Lunden and Thurlow (2020) evaluated $\mathrm{NO}_{2}, \mathrm{PM}_{2.5}, \mathrm{BC}$, and CO concentrations related to COVID-19, from March 9 to March 20 in 2020 and compared these concentrations for the same time periods in 2017, 2018 and 2019. They found a notable decrease of approximately $16 \%$ for $\mathrm{CO}, 16 \%$ for $\mathrm{PM}_{2.5}, 20 \%$ for $\mathrm{NO}_{2}$ and $29 \%$ for BC during 2020 compared with levels from 2017 through 2019. Furthermore, Safarian et al. (2020) reported that $\mathrm{CO}_{2}$ emissions worldwide in March 2020 has been $7 \%$ lower comparing to previous time.
The first COVID-19 case and death announced in Turkey were on 11 and 17 March 2020, respectively. The government then advised hand washing, physical distancing, and staying at home to slow or stop transmission of the virus. However, since 16 March 2020, the measures taken have been more restrictive, e.g., school closures, and people older than 65 are prevented from leaving their homes. Due to these prohibitions and the spread of virus, anthropogenic activities such as transportation, industry, and shopping have been significantly reduced since 16 March 2020. The primary purpose of this study is to describe the preliminary change in air pollutant levels before and after the implementation of COVID-19 measures in Istanbul.

\section{METHODS}

\section{COVID-19 in Turkey}

Fig. 1 shows the number of COVID-19 cases and deaths in Turkey from 11 to 31 March 2020. Some restrictions implemented by the government to slow down the spread of the virus are noted in the Fig. 1. The Health Ministry of the Turkish Republic has announced the number of cases and deaths daily for the entire country since 11 March. They have announced the number of cases and deaths daily for each city since 3 April 2020. This study includes the data up to 31 March to assess the preliminary effects on air pollution due to the measures. In March, the number of cases in Istanbul had not been announced, but according to the data announced on 28 July, there had been 227019 cases and 5630 deaths in Istanbul. This outcomes indicates that approximately $58 \%$ of the total cases and $42 \%$ of the total deaths were in Istanbul (TR-HM, 2020).

The measures taken against the spread of the virus primarily reduced activities in cities. As a result of these measures, there was a clear decrease in the density of traffic. The hourly mean traffic density from 1 to 31 March 2020 in Istanbul was prepared by the Istanbul Metropolitan Municipality (IMM) and is presented in Fig. 2. The other major change due to the COVID-19 response measures has been a decrease in the level of human activity outside the home. The mean population growth of Istanbul is approximately $1.4 \%$ annually, and the population was 15520000 in 2019 (IMM, 2020 b). According to IMM statistics, $25 \%$ of the population in Istanbul stayed at home before implementation of the virus measures, but this proportion has increased to $84 \%$ after the COVID-19 measures (IMM, 2020b). Another effect of the virus measures has been on industry. Many factories have stopped or reduced their activities due to the spread of the virus. However, statistical information on this situation is not currently available.

\section{Air Pollution Measurements in Istanbul}

Istanbul is a city divided into two sides by the Bosphorus Channel: European and Asian. The population of the European side is twice as high as the Asian side, and accordingly, a higher traffic density is much more evident (Unal et al., 2020). The Asian side of Istanbul has a newer infrastructure than the European side, while the latter has more historical sites and buildings. Nevertheless, construction has been 


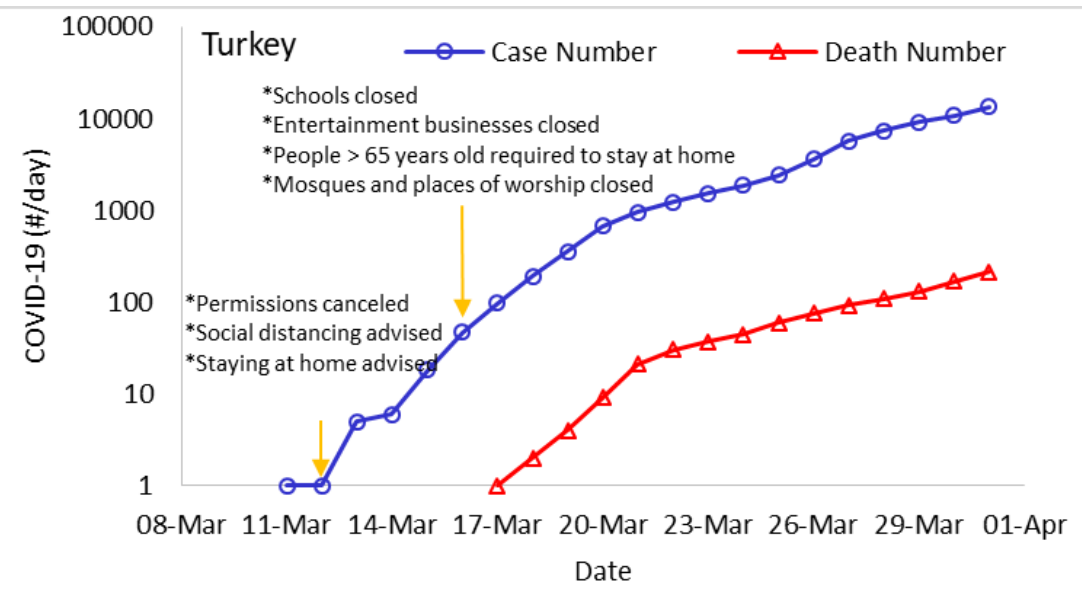

Fig. 1. COVID-19 cases and deaths in Turkey from 11 March to 31 March 2020.

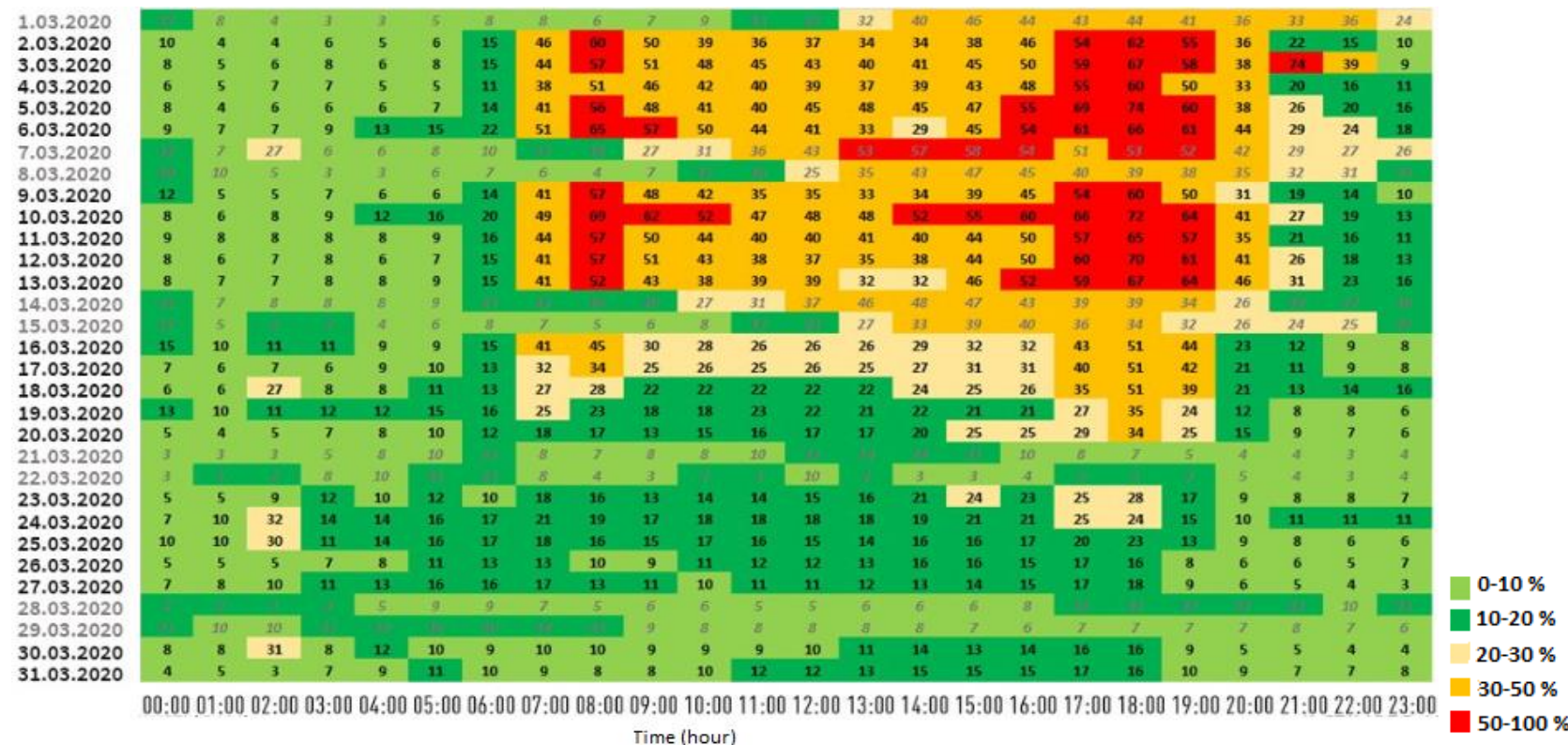

Fig. 2. Hourly traffic density in Istanbul (\%) from 1 March to 31 March 2020 (IMM, 2020a).

increasing dramatically on the European side of Istanbul (Shoman et al., 2019), which already has a higher building density (Unal et al., 2020). Due to these fundamental differences, this study aims to evaluate the effects of COVID-19 measures on air pollution on the European and Asian sides, separately.

There are 38 air quality monitoring stations in Istanbul; 26 are operated by the IMM and 12 are operated by the Ministry of Environment and Urban Planning (MoEUP) in Istanbul according to European and United States standards (IMM, 2020b). Of these, 21 and 14 of these stations are located on the European and Asian sides of Istanbul, respectively. For this study, the data, recorded as hourly means at all stations between 1 and 31 March 2020, were examined and at least one urban station and one traffic station was selected from both areas of Istanbul to evaluate the effect of COVID-19 measures on air pollution. The primary criterion for data selection was that at least $90 \%$ of the hourly data coverage and meteorological parameters were measured simultaneously.

Fig. 3 shows the location of the stations in Istanbul and Table 1 describes the stations and the parameters used in this study. The air quality parameters $\mathrm{NO}_{x}, \mathrm{SO}_{2}, \mathrm{CO}, \mathrm{PM}_{10}$ and $\mathrm{PM}_{2.5}$ were monitored continuously at these stations, but all pollutants are not necessarily measured at all stations. The traffic stations were generally located near major arterial roads. The distances from roads were $45 \mathrm{~m}$ for Uskudar, $10 \mathrm{~m}$ for Selimiye, $6 \mathrm{~m}$ for Beşiktaş, $4 \mathrm{~m}$ for Çatladıkapı, and $3 \mathrm{~m}$ for Mecidiyeköy. Eight stations were managed by the IMM and one (Mecidiyeköy) was managed by the MoEUP. The Bagcilar and Kadıköy districts represented urban areas in the heavily populated parts of Istanbul.

All air pollutants and meteorological data used in this study were acquired from the database of the Istanbul air quality measurement system (www.havakalitesi.ibb.gov.tr). Data validation is conducted routinely by the Air Quality 




Fig. 3. The location of air quality measurement stations.

Table 1. Descriptions of urban and traffic air quality monitoring stations in Istanbul. All station were managed by IMM, except Mecidiyeköy, which was managed by MoEUP.

\begin{tabular}{lllllll}
\hline Sides & Station Name & Station Type & Measured Parameters & Latitude & Longitude & Altitude \\
\hline Europe & Bağcılar & Urban & $\mathrm{PM}_{10}, \mathrm{PM}_{2.5}, \mathrm{CO}, \mathrm{NO}_{2}, \mathrm{SO}_{2}$ & 41.0327 & 28.8429 & 39 \\
& Beşiktaş & Traffic & $\mathrm{CO}, \mathrm{SO}_{2}$ & 41.0520 & 29.0094 & 85 \\
& Fatih-Çatladikap1 & Traffic & $\mathrm{PM}_{2.5}, \mathrm{NO}_{2}$ & 41.0023 & 28.9751 & 11 \\
& Mecidiyeköy & Traffic & $\mathrm{PM}_{10}$ & 41.0357 & 28.5940 & 95 \\
Asia & Kadiköy & Urban & $\mathrm{PM}_{10}, \mathrm{PM}_{2.5}, \mathrm{CO}, \mathrm{SO}_{2}$ & 40.9908 & 29.0333 & 6 \\
& Sancaktepe & Urban & $\mathrm{NO}_{2}$ & 41.0032 & 29.2259 & 114 \\
& Üsküdar & Traffic & $\mathrm{PM}_{10}, \mathrm{PM}_{2.5}, \mathrm{SO}_{2}$ & 41.0142 & 29.0246 & 70 \\
& Selimiye & Traffic & $\mathrm{NO}_{2}$ & 41.1279 & 29.0484 & 15 \\
\hline
\end{tabular}

Monitoring Center of MoEUP and by IMM. Moreover, before the analyses in this study, all data were checked for robustness; to detect anomalous records; for irregular, zero, negative values; and for outliers by a manual inspection of the data for quality control. Many researchers have used these data and described the processing of measurements in Istanbul (Capraz et al., 2016; Yurtseven et al., 2018; Guclu et al., 2019; Onay et al., 2019, Flores et al., 2017); a detailed measurement description can be found in Sahin et al. (2020).

\section{Statistical Analyses}

The data sets were split into two parts: the first represents data before COVID-19 measures from 1 to 15 March, and the second represents data after COVID-19 measures from 16 to 31 March 2020. Hourly air pollution data was extracted from the database of the Istanbul air quality measurement system and daily averages calculated for further graphical and statistical analysis. All statistical analyses were made using Excel, SPSS and R programs. Polar plots and diurnal variation plots were created using the open air package of $\mathrm{R}$ version 3.1.2 (R Core Team, 2015). Detailed descriptions of the statistical techniques used in this study can be found in Sahin et al. (2020).

\section{RESULTS AND DISCUSSIONS}

Table 2 shows the descriptive statistics for the parameters at the urban and traffic sites in Istanbul based on daily values from 1-15 March 2020 (before COVID-19 measures) and 16-31 March 2020 (after COVID-19 measures). Fig. 4 shows the daily average concentration of air pollutants and meteorological parameters in Istanbul from 1 March 2020 to 31 March 2020. Between 1 and 15 March 2020, the highest daily mean concentrations were $69.9 \pm 21.3 \mu \mathrm{g} \mathrm{m}^{-3} \mathrm{PM}_{10}$ at a traffic station on the European side, $37.0 \pm 15.4 \mu \mathrm{g} \mathrm{m}^{-3} \mathrm{PM}_{2.5}$ at an urban station on the Asian side, $100.7 \pm 21.4{\mu \mathrm{g} \mathrm{m}^{-3}}^{-3}$ $\mathrm{NO}_{2}$ at a traffic station on the Asian side, $1080 \pm 489 \mu \mathrm{g} \mathrm{m}^{-3}$ $\mathrm{CO}$ at an urban station on the Asian side, $7.1 \pm 1.6 \mu \mathrm{g} \mathrm{m}^{-3}$ $\mathrm{SO}_{2}$ at an urban station on the Asian side.

The comparison of the average concentration of all pollutants between 1-15 March 2020, before COVID-19 and 16-31 March 2020, after COVID-19 clearly shows that there 
Table 2. Values of all measured parameters at urban and traffic sites in Istanbul based on daily values from 1-15 March 2020 (before Covid-19 measures) and 16-31 March 2020 (after Covid-19 measures).

\begin{tabular}{|c|c|c|c|c|c|c|c|c|}
\hline \multirow[t]{2}{*}{ Parameters } & \multirow{2}{*}{$\begin{array}{l}\text { Side of } \\
\text { Istanbul }\end{array}$} & \multirow[b]{2}{*}{ Type } & \multicolumn{3}{|c|}{$1-15$ March 2020} & \multicolumn{3}{|c|}{ 16-31 March 2020} \\
\hline & & & Mean \pm ss & Median & Maximum & Mean \pm ss & Median & Maximum \\
\hline \multirow{4}{*}{$\begin{array}{l}\mathrm{PM}_{10} \\
\left(\mu \mathrm{g} \mathrm{m}^{-3}\right)\end{array}$} & Europe & Urban & $61.9 \pm 31.0$ & 53.7 & 122.0 & $42.4 \pm 31.5$ & 35.4 & 126.2 \\
\hline & & Traffic & $69.9 \pm 21.3$ & 67.6 & 113.5 & $43.9 \pm 21.4$ & 36.1 & 81.4 \\
\hline & Asia & Urban & $59.8 \pm 34.3$ & 55.9 & 122.0 & $38.2 \pm 30.2$ & 34.8 & 102.6 \\
\hline & & Traffic & $43.9 \pm 16.8$ & 39.2 & 72.1 & $24.8 \pm 11.4$ & 26.3 & 42.0 \\
\hline \multirow{4}{*}{$\begin{array}{l}\mathrm{PM}_{2.5} \\
\left(\mu \mathrm{g} \mathrm{m}^{-3}\right)\end{array}$} & Europe & Urban & $32.9 \pm 15.4$ & 29.0 & 67.4 & $21.2 \pm 12.1$ & 21.0 & 41.9 \\
\hline & & Traffic & $26.2 \pm 8.2$ & 26.3 & 42.0 & $21.2 \pm 9.2$ & 21.5 & 36.1 \\
\hline & Asia & Urban & $37.0 \pm 15.4$ & 35.4 & 63.0 & $23.3 \pm 12.4$ & 22.4 & 42.0 \\
\hline & & Traffic & $23.4 \pm 8.6$ & 24.0 & 39.4 & $13.6 \pm 6.6$ & 13.4 & 26.0 \\
\hline \multirow{4}{*}{$\begin{array}{l}\mathrm{NO}_{2} \\
\left(\mu \mathrm{g} \mathrm{m}^{-3}\right)\end{array}$} & Europe & Urban & $66.4 \pm 19.5$ & 67.2 & 104.9 & $39.7 \pm 19.4$ & 32.8 & 91.0 \\
\hline & & Traffic & $71.9 \pm 18.0$ & 73.4 & 105.6 & $40.6 \pm 14.5$ & 38.7 & 72.7 \\
\hline & Asia & Urban & $43.0 \pm 17.0$ & 46.1 & 66.1 & $23.9 \pm 10.8$ & 21.5 & 49.2 \\
\hline & & Traffic & $100.7 \pm 21.4$ & 106.0 & 135.9 & $71.3 \pm 19.6$ & 67.9 & 117.2 \\
\hline $\mathrm{CO}$ & Europe & Urban & $717 \pm 432$ & 604 & 1722 & $303 \pm 225$ & 214 & 904 \\
\hline \multirow[t]{2}{*}{$\left(\mu \mathrm{g} \mathrm{m}^{-3}\right)$} & & Traffic & $462 \pm 136$ & 472 & 717 & $278 \pm 78$ & 284 & 403 \\
\hline & Asia & Urban & $1080 \pm 489$ & 1084 & 2024 & $578 \pm 256$ & 449 & 1142 \\
\hline $\mathrm{SO}_{2}$ & Europe & Urban & $4.9 \pm 2.4$ & 5.0 & 10.1 & $2.5 \pm 1.1$ & 2.0 & 4.7 \\
\hline \multirow[t]{3}{*}{$\left(\mu \mathrm{g} \mathrm{m}^{-3}\right)$} & & Traffic & $5.8 \pm 3.4$ & 6.2 & 13.1 & $3.0 \pm 1.8$ & 2.5 & 7.2 \\
\hline & Asia & Urban & $7.1 \pm 1.6$ & 7.0 & 10.0 & $4.7 \pm 1.3$ & 4.3 & 6.8 \\
\hline & & Traffic & $3.9 \pm 2.7$ & 4.0 & 9.9 & $1.2 \pm 0.9$ & 1.0 & 3.3 \\
\hline \multirow[t]{2}{*}{$\mathrm{WS}\left(\mathrm{m} \mathrm{s}^{-1}\right)$} & Europe & Avrg. & $1.8 \pm 1.3$ & 1.7 & 5.3 & $2.3 \pm 1.2$ & 2.4 & 5.6 \\
\hline & Asia & Avrg. & $1.4 \pm 1.1$ & 1.2 & 5.0 & $2.0 \pm 1.2$ & 2.0 & 5.0 \\
\hline \multirow[t]{2}{*}{$\mathrm{RH}(\%)$} & Europe & Avrg. & $65 \pm 14$ & 57 & 89 & $71 \pm 12$ & 74 & 88 \\
\hline & Asia & Avrg. & $71 \pm 14$ & 72 & 93 & $76 \pm 11$ & 79 & 91 \\
\hline \multirow[t]{2}{*}{$\mathrm{P}$ (mbar) } & Europe & Avrg. & $1012 \pm 5$ & 1012 & 1024 & $1016 \pm 6$ & 1015 & 1030 \\
\hline & Asia & Avrg. & $1014 \pm 5$ & 1015 & 1026 & $1020 \pm 5$ & 1019 & 1032 \\
\hline $\operatorname{Max} . T\left({ }^{\circ} \mathrm{C}\right)$ & Asia & Avrg. & $16.8 \pm 3.7$ & 16.0 & - & $11.4 \pm 2.5$ & 11.0 & - \\
\hline
\end{tabular}

were significant reductions. The daily mean concentrations of pollutants measured at all stations decreased during the last two weeks of March compared to the first two weeks of March: from 43.6-69.9 to $24.8-46.2 \mu \mathrm{g} \mathrm{m}^{-3}$ in $\mathrm{PM}_{10}$, from 23.1-37.0 to $12.2-23.3 \mu \mathrm{g} \mathrm{m}^{-3}$ in $\mathrm{PM}_{2.5}$, from $41.3-100.7$ to $24.3-71.9 \mu \mathrm{g} \mathrm{m}^{-3}$ in $\mathrm{NO}_{2}$, from $462-1080$ to $278-578 \mu \mathrm{g} \mathrm{m}^{-3}$ in $\mathrm{CO}$, from $3.9-7.1$ to $1.2-4.7 \mu \mathrm{g} \mathrm{m}^{-3}$ in $\mathrm{SO}_{2}$ (Table 2). These results are likely related to the reduction in human, traffic, and industrial activities due to the measures taken against the spread of COVID-19.

Fig. 4 shows the temporal pattern of daily average pollutant concentrations. Generally, the decreasing trend of pollutant concentrations can be seen clearly in the graphs. Before 16 March, the level of $\mathrm{PM}_{10}, \mathrm{PM}_{2.5}$ and $\mathrm{NO}_{2}$ were typically above the EU daily limits of $50 \mu \mathrm{g} \mathrm{m}^{-3}, 25 \mu \mathrm{g} \mathrm{m}^{-3}$ and $50 \mu \mathrm{g} \mathrm{m}^{-3}$, respectively. The EU daily limit for $\mathrm{NO}_{2}$ was exceeded for 14 days from 1 to 15 March at the urban stations on the European side of Istanbul and at both traffic stations. However, after 16 March, the mean concentration of $\mathrm{NO}_{2}$ only exceeded the limit on three days at the urban and traffic stations on the European side of Istanbul. In contrast, despite the significant reduction in concentration, the $\mathrm{NO}_{2}$ limits were exceeded on 14 days after the COVID-19 measures were implemented. Because at this station the mean $\mathrm{NO}_{2}$ levels are typically two times higher than the limit, the decrease was not sufficient to bring the postCOVID-19 measures level below the limit. The Catladikapı and Selimiye traffic stations are located near the Eurasia Tunnel, which is a road under the Bosphorus Strait in the city of Istanbul. The Selimiye station is located $120 \mathrm{~m}$ south of the tunnel stack on the Asian side of Istanbul. The Catladikapı station is located $100 \mathrm{~m}$ north of the tunnel stack on the European side of Istanbul. Because these stations are very close to the tunnel portals and stacks, the $\mathrm{NO}_{2}$ concentrations are very high and reflect the traffic pollutants on the two sides of Istanbul. Gokce et al. (2020) investigated changes in the air pollutant concentrations at these stations 1 year before and 2 years after the tunnel began operation. They reported that the average $\mathrm{NO}_{2}$ concentrations increased by approximately $9-24 \%$.

Fig. 5 shows the reduction in air pollutants from 1-15 March (before COVID-19 measures) to 16-31 March (after COVID-19 measures) at the urban and traffic stations on the European and Asian sides of Istanbul. A comparison of the average values before and after COVID-19 measures, clearly shows that there were significant reductions in pollutants: 32-43\% ( $\left.\mathrm{PM}_{10}\right), 19-47 \%\left(\mathrm{PM}_{2.5}\right), 29-44 \%\left(\mathrm{NO}_{2}\right), 40-58 \%$ (CO) and 34-69\% $\left(\mathrm{SO}_{2}\right)$. The $\mathrm{NO}_{2}$ decreases were greater at the traffic station on the European side than those on the Asian side. $\mathrm{NO}_{2}$ measurements were from the traffic stations near major roads on the European and Asian sides (Catladikapi and Selimiye, respectively). Traffic density and population density are both higher on the European side, thus the COVID-19 measures likely led to the more dramatic impact 



Fig. 4. Daily average concentration of air pollutants and meteorological parameters in Istanbul from 1 March 2020 to 31 March 2020. (EU-T: traffic station in Europe, EU-U: urban station in Europe, AS-T: traffic station in Asia, AS-U: urban station in Asia). 


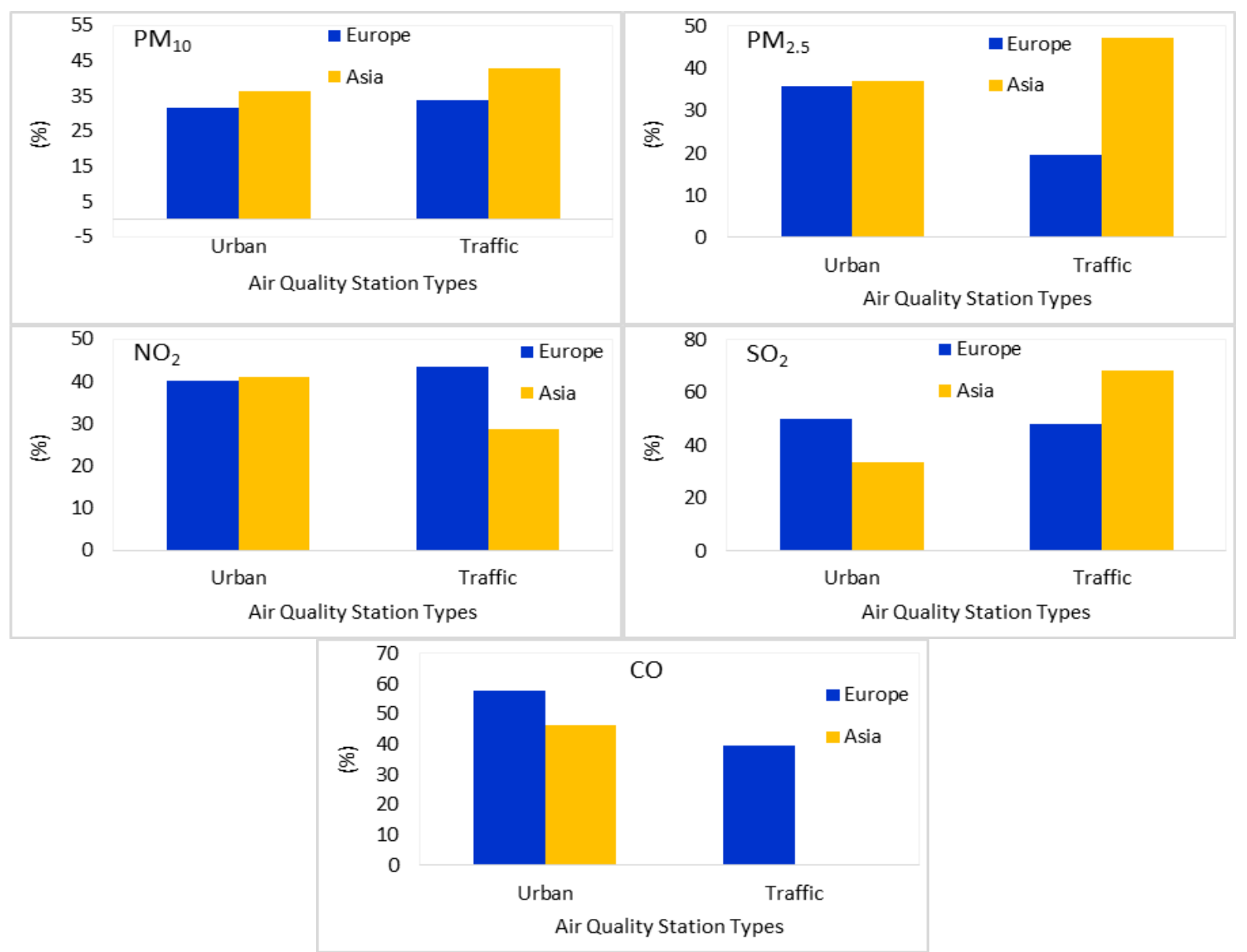

Fig. 5. The reduction (\%) in air pollutants from 1-15 March (before COVID-19 measures) to 16-31 March (after COVID19 measures) at the urban and traffic stations on the European and Asian sides of Istanbul.

on that side of the channel. In contrast, the decrease in $\mathrm{PM}_{10}$, $\mathrm{PM}_{2.5}$ and $\mathrm{SO}_{2}$ at the traffic stations on the Asian side were greater than those on the European side. The datasets for these pollutants on the Asian side were taken from the Usküdar traffic station, which is impacted by both traffic and other urban sources. It is also very close to the Bosphorus Channel, where ship emissions (especially $\mathrm{SO}_{2}$ ) contribute to the air pollution, and was likely impacted by restrictions on international transportation activities. Furthermore, at the urban stations, the average $\mathrm{CO}$ and $\mathrm{SO}_{2}$ concentrations decreased by approximately $58 \%$ and $50 \%$, respectively, on the European side and by $46 \%$ and $34 \%$ on the Asian side. The high reduction of $\mathrm{CO}$ and $\mathrm{SO}_{2}$ on the European side may be related to the decrease in the need for domestic heating, depending on the population density and temperature increase. However, there were not substantial differences in reductions between the European and Asian sides at the urban stations for $\mathrm{PM}_{10}(36-32 \%), \mathrm{PM}_{2.5}(36-37 \%)$ and $\mathrm{NO}_{2}(40-41 \%)$. All results indicate that due to the measures taken across Turkey and in Istanbul to control the spread of the virus, indicators of anthropogenic activities such as traffic density have decreased and as a result, the air pollution has also been reduced.

Fig. 6 shows the temporal variation in air pollutants at urban and traffic stations on the European and Asian sides of Istanbul on an hourly and daily basis. A comparison of diurnal variation before and after COVID-19 measures clearly shows that all air pollutant concentrations were higher before COVID-19 measures than after. Student's t-tests were conducted using SPSS to see the difference between peak hours before and after COVID-19 measures, for all pollutants measured in each stations. Particularly at peak traffic hours, the average concentrations of $\mathrm{NO}_{2}, \mathrm{PM}_{2.5}, \mathrm{PM}_{10}$ and $\mathrm{CO}$ were significantly $(\mathrm{p}<0.01)$ decreased after COVID-19 measures, according to the t-test. The hourly average concentrations of $\mathrm{NO}_{2}$ reached their highest levels at the traffic stations in the morning from 6:00-7:00 and in the evening from 17:0020:00 (approximately $100 \mu \mathrm{g} \mathrm{m}^{-3}$ and $120 \mu \mathrm{g} \mathrm{m}^{-3}$, respectively, on the European side). There are similar peaks from 16-31 March but the mean concentration are two times lower than the period 1-15 March.

All daily graphs showed a similar trend. Before the COVID-19 measures, the highest pollutant levels occurred from Monday to Wednesday. However, after the COVID19 measures, all pollutant concentrations reached their peak values on Friday and Saturday. On these days, the increases for $\mathrm{PM}_{10}$ and $\mathrm{PM}_{2.5}$ clearly exceed those before COVID-19 measures. There may be three reasons for this result. First, there is an increase in traffic in the evening on Friday and Saturday (Fig. 2). Because schools were closed after 16 

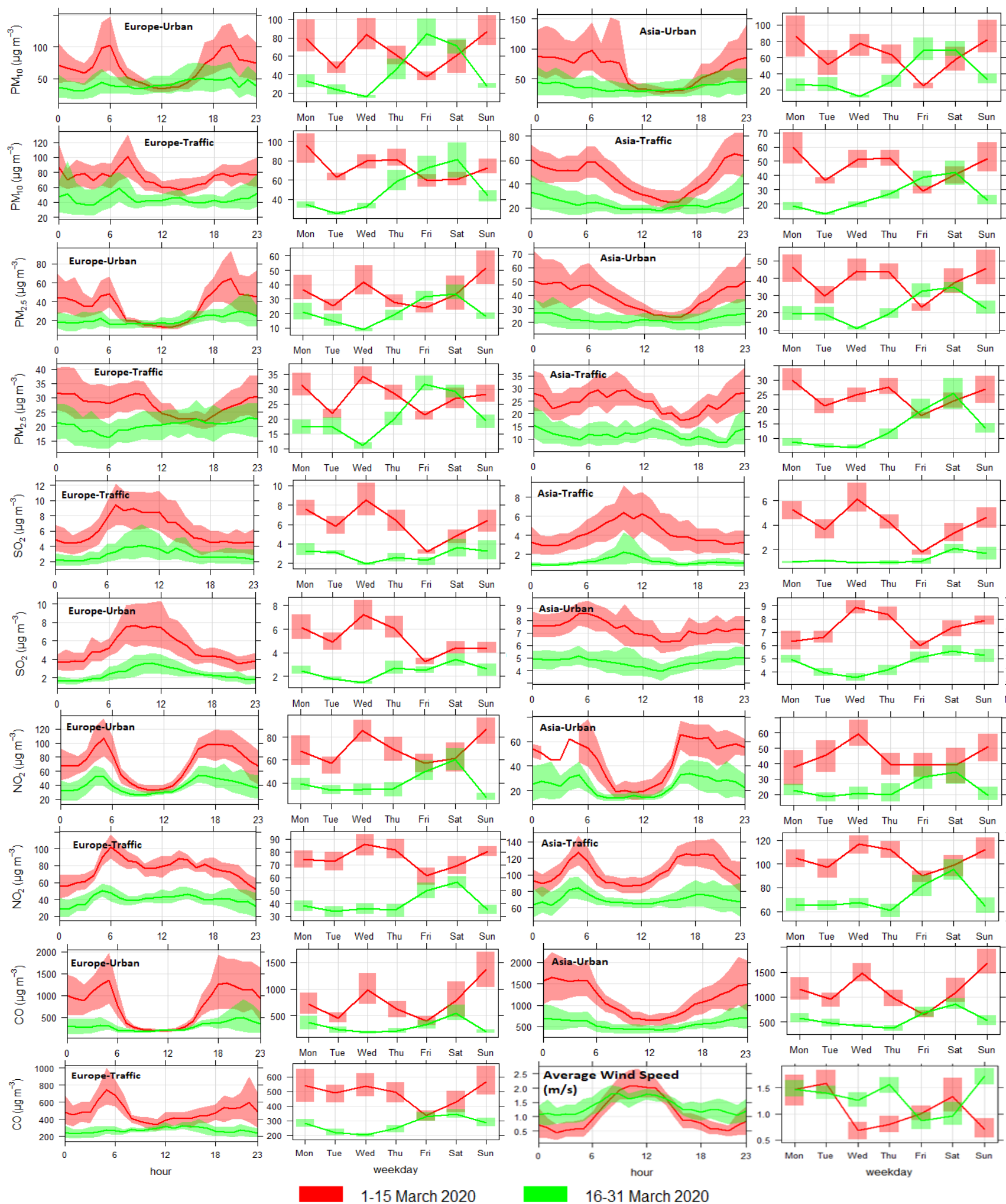

1-15 March 2020

16-31 March 2020
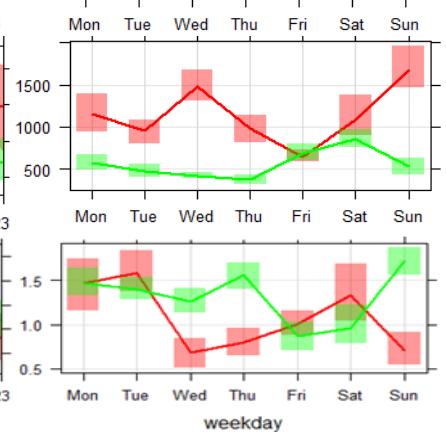

Fig. 6. The hourly and weekly variation in air pollutants on the European and Asian sides of Istanbul and the average wind speed before and after COVID-19 measures.

March 2020, people preferred to leave the city on 21-22 March (e.g. to a village house). As a result, all pollution level may have increased at that time in response to the increasing traffic (Fig. 4). Second, the peak value of $\mathrm{PM}_{10}$ was seen on
27 March (on Saturday) due to the Saharan dust event in Istanbul (Fig. 4, $\mathrm{PM}_{10}$ plot). Third, there was a small decrease in wind speed on Friday and Saturday and an increase on Wednesday, Thursday and Sunday after 16 March (Fig. 6). 
As indicated by Fig. 6, wind played a crucial role in decreasing pollutant levels during the COVID-19 measures. Polar plots are helpful to investigate local sources of atmospheric pollutants. Fig. 7 shows the polar plots of $\mathrm{NO}_{2}$ and $\mathrm{PM}_{2.5}$ at the urban and traffic stations on the European and Asian sides of Istanbul before and after COVID-19 measures. It is clearly seen that there were considerable concentration differences between before and after COVID-19 measures at the traffic stations for $\mathrm{NO}_{2}$ on the European side and for $\mathrm{PM}_{2.5}$ on the Asian side. In addition, $\mathrm{PM}_{2.5}$ and $\mathrm{NO}_{2}$ at the urban stations showed no strong association with a


Europe-Traffic

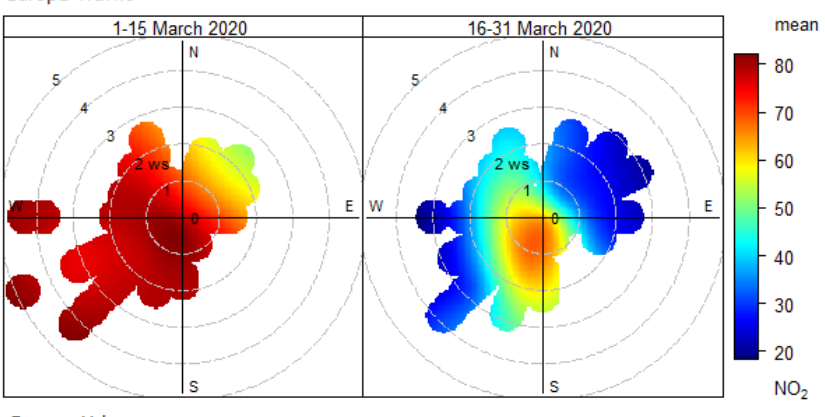

Europe-Urban

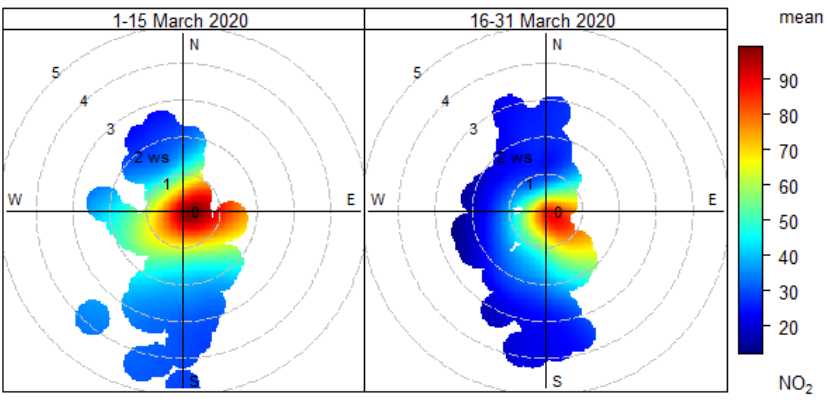

Asia-Urban
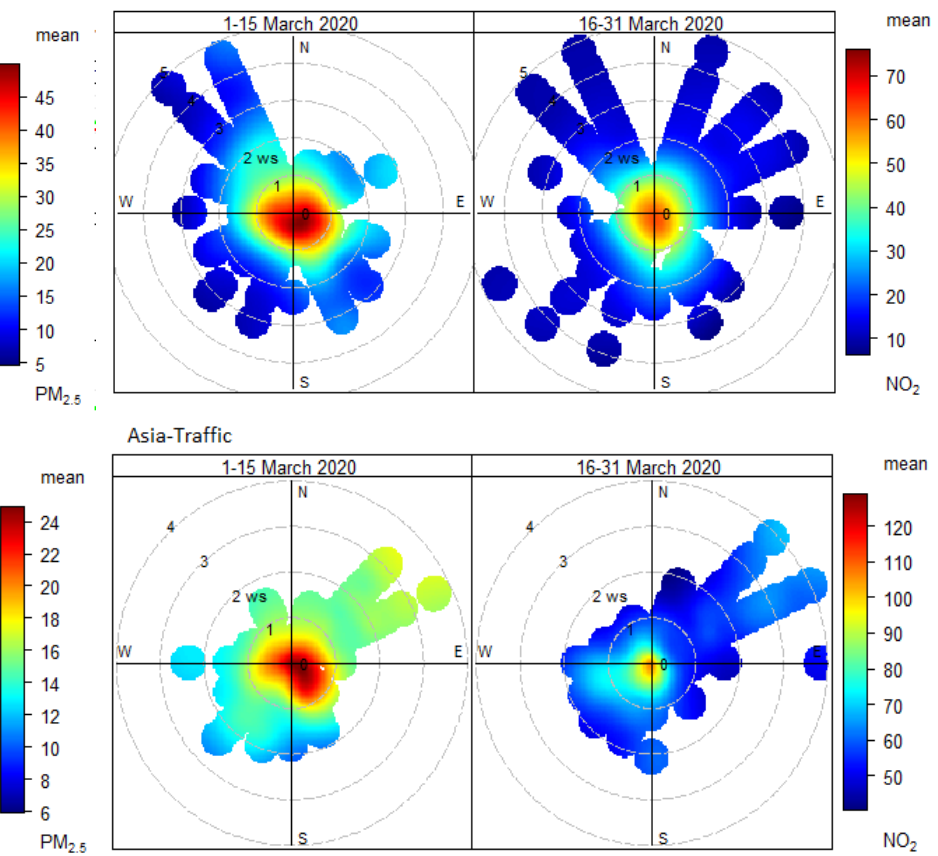

Fig. 7. Polar Plots of $\mathrm{NO}_{2}$ and $\mathrm{PM}_{2.5}$ at urban and traffic stations on the European and Asian sides of Istanbul before and after COVID-19 measures. 
measured at the traffic station in the European side were also likely affected by ship emissions in addition to traffic (Fig. 3). This result is also supported by the diurnal graphs of $\mathrm{SO}_{2}$ showing the peak values in the middle of days in Fig. 6.

To better understand the effect of COVID-19 measures on the decrease in air pollutant concentrations, the daily mean concentration from 16 to 31 March 2017-2019 was compared with the mean values measured from 16-31 March 2020 (Fig. 8). It can be seen that the mean concentrations in 2017 2019 were generally higher than at the same time in 2020 . The mean $\mathrm{NO}_{2}$ concentrations in 2019 were 1.6-2.4 times higher than those in $2020\left(24-35 \mu \mathrm{g} \mathrm{m}^{-3}\right)$, except at the traffic station in Asia (Selimiye). As mentioned previously, this station is very close to the Eurasia Tunnel stack and Gokce et al. (2020) reported that the pollution level at this station has increased by approximately $24 \%$ since the tunnel began operating in 2016.

Considerable reductions were found for $\mathrm{PM}_{10}(36-44 \%)$, for $\mathrm{PM}_{2.5}(10-36 \%)$, for $\mathrm{NO}_{2}(18-59 \%)$, for $\mathrm{CO}(4-60 \%)$, and for $\mathrm{SO}_{2}(28-55 \%)$ in this study compared with the average concentrations in 2017-2019 periods. The average percent reduction in $\mathrm{NO}_{2}$ observed in this study is higher than that in San Francisco (20\%) (Lunden and Thurlow, 2020) and similar in China (46\%) (Zhao et al., 2020), but lower than that in Barcelona (51\%) (Tobías et al., 2020), in
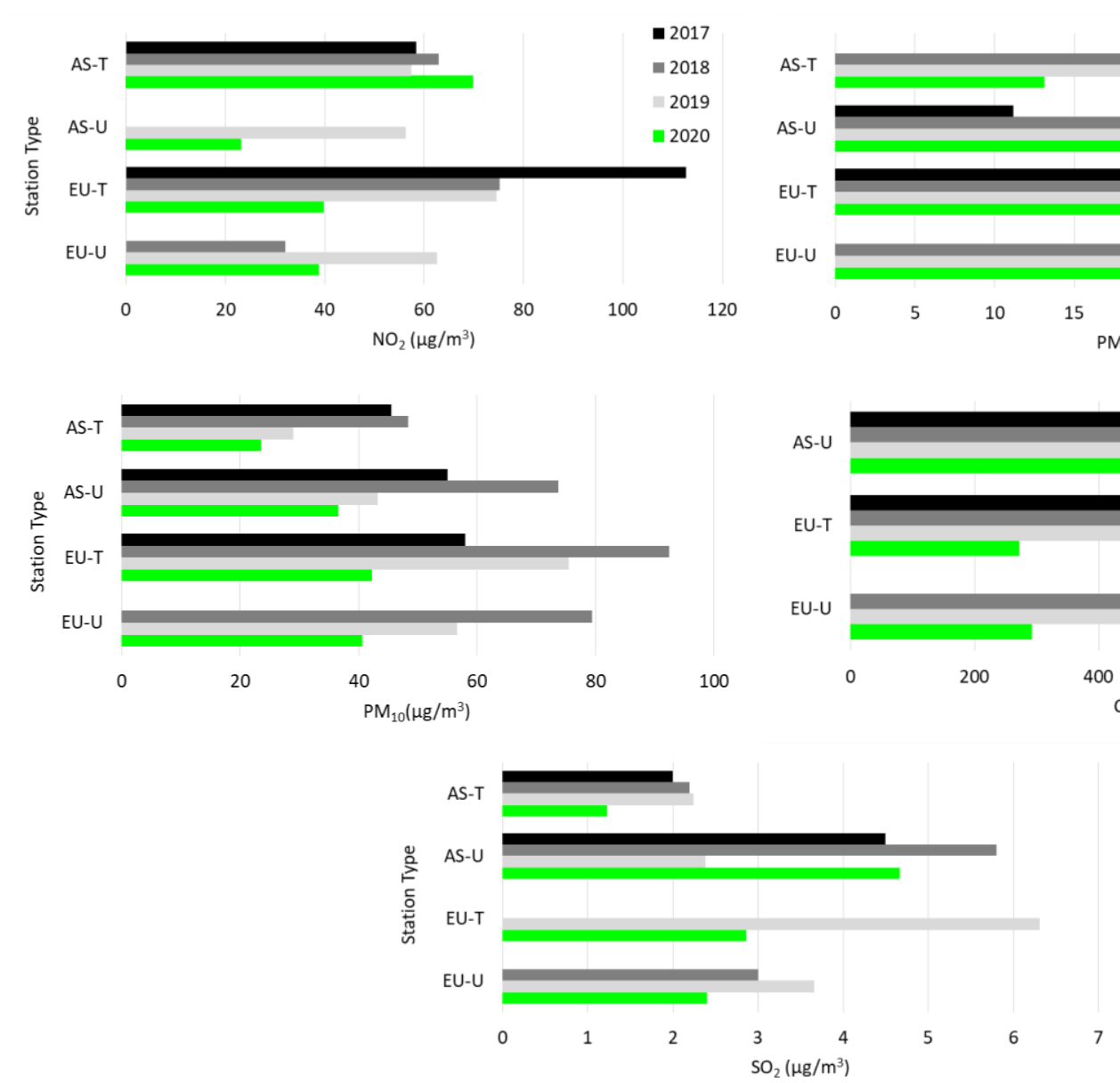

Fig. 8. Comparison of the daily mean concentrations of pollutants from 16 to 31 March 2019, 2018, 2017 and from 16 to 31 March 2020 (COVID-19 measures).
Delhi (51\%) (Jain and Sharma, 2020) and in China comparing the data in March 2017-2019 and 2020 (56\%) (Xu et al., 2020).

Fig. 8 shows that there were continuous reductions in $\mathrm{PM}_{2.5}$ and $\mathrm{PM}_{10}$ from 2017 to 2020. Changes in particulate matter levels can be less directly apparent in the data recorded during COVID-19 measures and will require longer time trend analyses with assessing the impact of meteorology by de-weathering the air quality data. This reflects the wider range of PM sources and the importance of regional, as well as local, emissions. In cities with a high $\mathrm{PM}_{2.5}$ concentration, more decreases are observed due to the decrease in anthropogenic sources during COVID-19 measures period such as in Delhi (Jain and Sharma, 2020) and Malaysia (Mohd Nadzir et al., 2020) $41 \%$ and 20 to $60 \% \mathrm{PM}_{2.5}$ reduction have been reported, respectively.

\section{CONCLUSIONS}

In conclusion, the temporary reduction in air pollutants observed at present in Istanbul provides us with an understanding of background urban air pollution levels and what might be possible for future air conditions in Istanbul. The results of this study clearly indicate that at the traffic station on the European side, the greatest reductions have
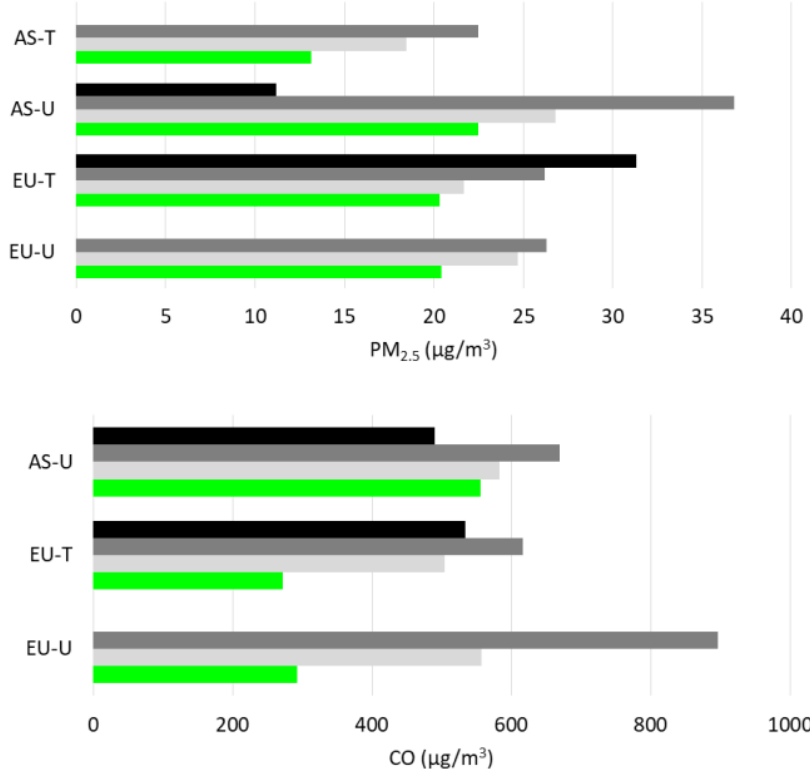
000 
been in $\mathrm{NO}_{2}$, which comes primarily from vehicle exhaust; both between the first two weeks and the last two weeks of March 2020 (44\%) and between 2017-2019 and 2020 (65$47 \%$ ). At the urban station on the European side of Istanbul, the greatest reductions were in $\mathrm{CO}(58 \%)$ and $\mathrm{SO}_{2}(50 \%)$. The significant decrease in $\mathrm{PM}_{10}$ and $\mathrm{PM}_{2.5}$ from 19 to $47 \%$ at the traffic sites and from 32 to $37 \%$ at the urban sites before and after COVID-19 measures in March 2020. The greatest reductions in $\mathrm{NO}_{2}$ and $\mathrm{PM}_{2.5}$ at the traffic sites indicate that the air pollution at that location could be reduced by lowered traffic levels or increasing the proportion of cleaner vehicles such as electrified or hybrid vehicles. This is an important finding for practitioners, policymakers and politicians and should inform initiatives to protect public health These results also allow us to discuss what air quality standards might be feasible, particularly for secondary pollutants. Turkey does not yet have $\mathrm{PM}_{2.5}$ standards. Based on the results of this study, if the city reduced activities such as traffic density by less than $20 \%$, the EU and WHO standards would not be exceeded.

Pandemics, such as COVID-19; will continue to be a problem in the future. It is inevitable that this short-term reduction in air pollution will be reversed when the crisis ends and conditions return to the old-normal. To protect the community in the future, government policy makers and scientists must prioritize reductions in air pollution based on scientific evidence. This study covered a short time frame due to the aiming to show preliminary effects of COVID-19 measures in air pollution. Turkey has continued COVID-19 measures to slow or stop transmission, including prohibiting intercity transportation, restricting movements of those above 65 years old and below 20 years old, prohibiting large-scale private and public gatherings, closing all schools, restricting private and public transportation, instituting a weekend or holiday lockdown, etc. All these measures will affect air pollution. Long-term studies should be conducted, possibly examining the cases and deaths for each area in Istanbul compared with pollutants, vehicle numbers on traffic and meteorological data.

\section{COMPETING INTERESTS}

The author declares no conflict of interest.

\section{ACKNOWLEDGMENTS}

This research has been supported by the Scientific and Technical Research Council of Turkey (TUBITAK) (grant number 1059B191801445), the Research Fund of the University of Istanbul-Cerrahpaşa (grant numbers 25819 and 27174). The author thanks the Department of Environmental Protection and Control and the Istanbul Statistical Office of the Istanbul Metropolitan Municipality for their support in providing data on air pollutants, meteorological data and other statistics for Istanbul. The manuscript was edited for proper English language, grammar, punctuation, spelling, and overall style by one or more of the highly qualified native English speaking editors at ACS (the verification code F927-021A-8E1D-B7D7-DF73). Furthermore the author thanks Dr. Surindar Kishen Dhesi, Lecturer in Environmental Health and Risk Management, in the School of Geography, Earth and Environmental Sciences, University of Birmingham, UK to edit the manuscript to improve the English.

\section{REFERENCES}

Capraz, O., Efe, B. and Deniz, A. (2016). Study on the association between air pollution and mortality in İstanbul, 2007-2012. Atmos. Pollut. Res. 7: 147-154. https://doi.org/10.1016/j.apr.2015.08.006

Croft, D.P., Zhang, W., Lin, S., Thurston, S.W., Hopke, P.K., Masiol, M., Squizzato, S., van Wijngaarden, E., Utell, M.J. and Rich, D.Q. (2019). The association between respiratory infection and air pollution in the setting of air quality policy and economic change. Ann. Am. Thorac. Soc. 16: 321-330. https://doi.org/10.1513/A nnalsATS.201810-6910C

Flores, R.M., Kaya, N., Eşer, Ö. and Saltan, Ş. (2017). The effect of mineral dust transport on $\mathrm{PM}_{10}$ concentrations and physical properties in Istanbul during 2007-2014. Atmos. Res. 197: 342-355. https://doi.org/10.1016/j.atmo sres.2017.07.009

Gokce, H.B., Arioglu, E., Copty, N.K., Onay, T.T. and Gun, B. (2020). Exterior air quality monitoring for the Eurasia Tunnel in Istanbul, Turkey. Sci. Total Environ. 699: 134312. https://doi.org/10.1016/j.scitotenv.2019.134312

Guclu, Y.S., Dabanli, I., Sisman, E. and Sen, Z. (2019). Air quality (AQ) identification by innovative trend diagram and AQ index combinations in Istanbul megacity. Atmos. Pollut. Res. 10: 88-96. https://doi.org/10.1016/j.apr.2018. 06.011

Isaifan, R.J. (2020). The dramatic impact of Coronavirus outbreak on air quality: Has it saved as much as it has killed so far? Global J. Environ. Sci. Manage. 6: 275-288. https://doi.org/10.22034/gjesm.2020.03.01

Istanbul Metropolitan Municipality (IMM) (2020a). Transport Management Center. https://uym.ibb.gov.tr/Y Harita/Harita_EN.aspx

Istanbul Metropolitan Municipality (IMM) (2020b). Istanbul Statistic Center. https://istatistik.istanbul/\#abou

Jain, S. and Sharma, T. (2020). Social and travel lockdown impact considering coronavirus disease (COVID-19) on air quality in megacities of India: Present benefits, future challenges and way forward. Aerosol Air Qual. Res. 20: 1222-1236. https://doi.org/10.4209/aaqr.2020.04.0171

Lelieveld, J., Pozzer, A., Pöschl, U., Fnais, M. and Haines, A. (2020). Loss of life expectancy from air pollution compared to other risk factors: A worldwide perspective. Cardiovascular Res. 7: 1334. https://doi.org/10.1093/cvr/ cvaa025

Lin, H., Ratnapradipa, K., Wang, X., Zhang, Y., Xu, Y., Yao, Z., Dong, G., Liu, T., Clark, J., Dick, R., Xiao, J., Zeng, W., Li, X., Qian, Z.M. and Ma, W. (2017). Hourly peak concentration measuring the $\mathrm{PM}_{2.5}$-mortality association: Results from six cities in the Pearl River Delta study. Atmos. Environ. 161: 27-33. https://doi.org/ 10.1016/j.atmosenv.2017.04.015

Lunden, M. and Thurlow, M. (2020, March 31). The 
stunning impact of COVID-19 social distancing on air pollution. GreenBiz Group. https://www.greenbiz.com/ar ticle/stunning-impact-covid-19-social-distancing-air-poll ution

Mills, I.C., Atkinson, R.W., Kang, S., Walton, H. and Anderson, H.R. (2015). Quantitative systematic review of the associations between short-term exposure to nitrogen dioxide and mortality and hospital admissions. BMJ Open 5: e006946. https://doi.org/10.1136/bmjopen-2014-006946.

Mohd Nadzir, M.S., Ooi, M.C.G., Alhasa, K.M., Bakar, M.A.A., Mohtar, A.A.A., Nor, M.F.F.M., Latif, M.T., Hamid, H.H.A., Ali, S.H.M., Ariff, N.M., Anuar, J., Ahamad, F., Azhari, A., Hanif, N.M., Subhi, M.A., Othman, M. and Nor. M.Z.M. (2020). The impact of movement control order (MCO) during pandemic COVID-19 on local air quality in an urban area of Klang Valley, Malaysia. Aerosol Air Qual. Res. 20: 1237-1248. https://doi.org/10.4209/aaqr.2020.04.0163

Onat, B., Şahin, Ü.A. and Sivri, N. (2017). The relationship between particle and culturable airborne bacteria concentrations in public transportation. Indoor Built Environ. 26: 1420-1428. https://doi.org/10.1177/142032 6X16643373

Onay, T.T., Copty, N.K. Gokce, H.B., Aydin-Sarikurt, D. Mumcu, M. and Arioglu E. (2019). Air quality impact assessment for the Eurasia Tunnel in Istanbul, Turkey. Environ. Monit. Assess. 191: 195. https://doi.org/10.1007 /s10661-019-7340-4

R Core Team (2015). R: A language and environment for statistical computing. $\mathrm{R}$ Foundation for Statistical Computing, Vienna, Austria. http://www.R-project.org/

Sahar Safarian, S., Unnthorsson, R. and Richter, C. (2020). Effect of coronavirus disease 2019 on $\mathrm{CO}_{2}$ emission in the world. Aerosol Air Qual. Res. 20: 1197-1203. https://doi.org/10.4209/aaqr.2020.04.0151

Sahin, U.A., Onat, B., Akın, O., Ayvaz, C., Uzun, B., Mangir, N., Dogan, M. and Harrison, R.M. (2020). Temporal variations of atmospheric black carbon and its relation to other pollutants and meteorological factors at an urban traffic site in Istanbul. Atmos. Pollut. Res. 11: 1051-1062. https://doi.org/10.1016/j.apr.2020.03.009

Setti, L., Passarini, F., de Gennaro, G., Di Gilio, A., Palmisani, J., Buono, P., Fornari, G., Perrone, M.G., Piazzalunga, A., Barbieri, P., Rizzo, E. and Miani, A. (2020). Evaluation of the potential relationship between Particulate Matter (PM) pollution and COVID-19 infection spread in Italy. Society Italiana Di Medicina Ambientale (SIMA), Universita Degli Studi Di Bari Aldo Moro. http://www.simaonlus.it/wpsima/wp-content/uplo ads/2020/03/COVID_19_position-paper_ENG.pdf
Shoman, W., Korkutan, M., Alganci, U., Tanik, A. and Demirel, H. (2019). Dynamic monitoring of land cover change: A recent study for Istanbul metropolitan area. Fresenius Environ. Bull. 28: 688-693.

Tobías, A., Carnerero, C., Reche, C., Massagué, J., Via, M., Minguillón, M.C., Alastuey, A. and Querol, X. (2020). Changes in air quality during the lockdown in Barcelona (Spain) one month into the SARS-CoV-2 epidemic. Sci. Total Environ. 726: 138540. https://doi.org/10.1016/j.sci totenv.2020.138540

TR-HM (Health Ministry of Turkey Republic) (2020). https://covid19bilgi.saglik.gov.tr/tr/gunluk-vaka

Unal, Y.S., Sonuç, C.Y., Incecik, S., Topcu, H.S., DirenÜstün, D.H. and Temizöz, H.P. (2020). Investigating urban heat island intensity in Istanbul. Theor. Appl. Climatol. 139: 175-190. https://doi.org/10.1007/s00704019-02953-2

Wang, P., Chen, K., Zhua, S., Wang, P. and Zhang, H. (2020). Severe air pollution events not avoided by reduced anthropogenic activities during COVID-19 outbreak. Resour. Conserv. Recycl. 158: 104814. https://doi.org/10.1016/j.resconrec.2020.104814

WHO (World Health Organization) (2020). Daily COVID19 statistics. https://www.who.int/emergencies/diseases/n ovel-coronavirus-2019

Xu, K., Cui, K., Young, L.H., Hsieh, Y.K., Wang, Y.F. Zhang, J. and Wan, S. (2020). Impact of the COVID-19 event on air quality in central China. Aerosol Air Qual. Res. 20: 915-929. https://doi.org/10.4209/aaqr.2020.04.0150

Yurtseven, E., Vehid, S., Bosat, M., Koksal, S. and Yurtseven, C.N. (2018). Assessment of ambient air pollution in Istanbul during 2003-2013. Iran. J. Public Health 47: 1137-1144.

Zhang, D., Li, Y., Chen, Q., Jiang, Y., Van An, C., Ding, Y., Yu, Y., Fan, Y., Shi, J., Luo, Y. and Zhou, W. (2019). The relationship between air quality and respiratory pathogens among children in Suzhou City. Ital. J. Pediatr. 45: 123. https://doi.org/10.1186/s13052-019-0702-2

Zhao, Y., Zhang, K., Xu, X., Shen, H., Zhu, X., Zhang, Y., Hu, Y. and Shen, G. (2020). Substantial changes in nitrate oxide and ozone after excluding meteorological impacts during the COVID-19 outbreak in mainland China. Environ. Sci. Technol. Lett. 7: 402-408. https://doi.org/10. 1021/acs.estlett.0c00304

Received for review, June 11, 2020 Revised, July 28, 2020 Accepted, August 1, 2020 